\title{
Seasonal development of female strobilus of stone pine (Pinus pinea L.)
}

\author{
B. Abellanas and J.A. Pardos
}

Laboratory of Plant Anatomy, Physiology and Genetics, E.T.S. Ingenieros de Montes, Ciudad Universitaria, 28040 Madrid, Spain

\section{Introduction}

The stone pine (Pinus pinea L.) prevails as a fruit tree rather than as a timber tree. Therefore, maximizing cone crops must be a primary goal for breeding performance (Pardos and Abellanas, 1988). Establishment, by grafting, of clone banks from selected provenances is a valid way to progress (Magini, 1965). Precise knowledge of the $4 \mathrm{yr}$ reproductive cycle of this species is necessary for an accurate evaluation of cone production and manipulation of the selected clones in the banks.

The object of the research described herein was to examine the morphology of the female strobilus and to describe the phenology of the reproductive cycle from seed-cone bud initiation to appearance of the embryo.

\section{Materials and Methods}

Female strobili and potentially reproductive buds were collected from randomly selected $P$. pinea L. grafts growing in a clone bank located at Castellón, Spain.

Buds and strobili were taken monthly from July 1987 to July 1988, fixed in FAA (formalin-acetic acid-ethanol), and stored in $70 \%$ ethanol until dissection. Then the samples were dehydrated and embedded in paraffin. Serial microtome sections were cut 7-9 $\mu \mathrm{m}$ thick, stained with safranin and fast-green, and examined under a light microscope.

\section{Results}

In April, just after flowering occurred, the development of the new long-shoot bud begins. The apical meristem enlarges and initiates primary cataphylls and the first axillary primordia.

In July, the axillary primordia begin to form secondary cataphylls, but they do not reach the differentiation stage, into either vegetative or reproductive structures, until December. During December and Janua$r y$, the secondary long-shoot buds differentiate, i.e., seed-cone buds and lateralbranch buds appear on the upper region of the primary long-shoot bud. 


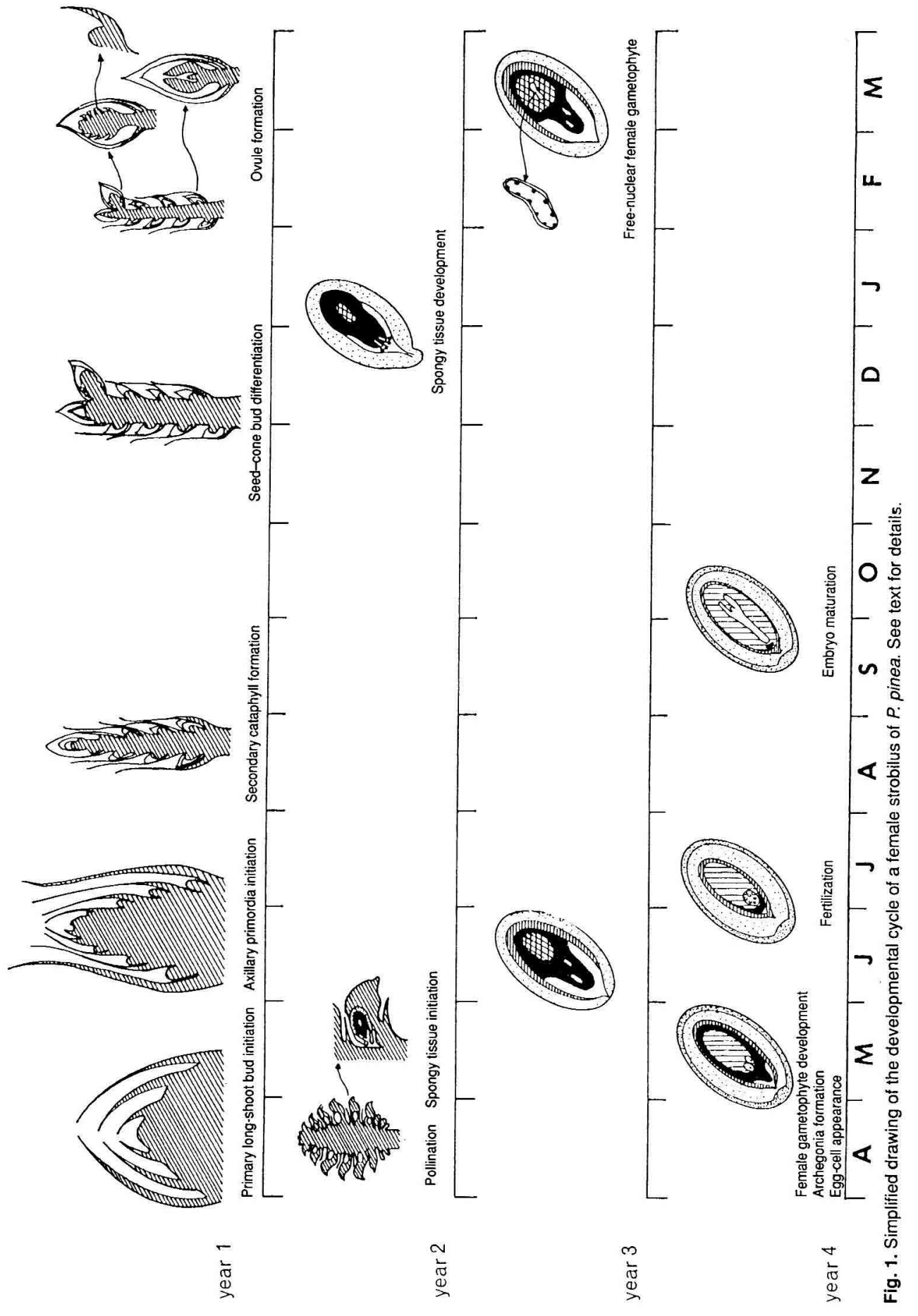


In February, the different bud types are distinct. At this time, the female buds initiate the first ovuliferous scales. However, the short-shoot buds are still undifferentiated, and appear as simple primordia covered with a number of secondary cataphylls. They continue forming new cataphylls until March, when almost all the ovuliferous scales have appeared and the ovules begin to form in their axils.

Around late March or early April, the mature seed-cone buds open and pollination takes place. Afterwards, the strobilus scales enlarge and the cone closes. Near the end of April, a hyaline cell appears in the center of each ovule. Division of this cell initiates the spongy tissue. During the whole next year of development, few changes in the ovule occur; the spongy tissue enlarges, the pollen tubes grow through the nucellus and the different layers of the integument, which will become the seed coat, begin to differentiate.

Not until February of the third year of development does the free-nuclear stage of the female gametophyte appear in the center of the greatly enlarged spongy tissue. From now on, the development of the female gametophyte is very fast. During the next month, the cell wall forms and separates the female gametophyte into many small cells. In April, the archegonia appear at the nucellar end of the gametophyte, with the egg cell well formed. In early June, the egg cell has developed large vacuoles and soon afterwards fertilization occurs. In mid-July, the embryo begins its development, which will be finished at the end of this summer.

\section{Discussion and Conclusion}

The stone pine ( $P$. pinea $L$.) has a peculiar reproductive cycle because it takes one more year to complete than most of other Pinus species (Owens and Molder, 1984; Pattinson et al., 1989).

The main conclusion of this study is that the phases of female strobilus development in this species are similar to those of other pines but the timing of some of them is delayed. The first steps are similar but female gametophyte development and fertilization are delayed over one year.

\section{References}

Magini E. (1965) Esperienze sull'innesto all'aperto del pino domestico (Pinus pinea L.). Firenze, pp. 20

Owens J.N. \& Molder M. (1984) The reproductive cycle of Lodgepole pine. Information Service Branch, Ministry of Forestry, British Columbia. pp. 29

Pardos J.A. \& Abellanas B. (1988) El pino piñonero: especie forestal de interés fruticola. Frut Rev. Fruticultura 3, 162-170

Pattinson J.V., Burley J. \& Geary T.F. (1969) Development of the ovulate strobilus in Pinus kesiya Royle ex Gordon (syn Pinus khasya Royle) in relation to controlled pollination in Zambia. Silv. Genet. 18, 108-111 